\title{
Ecological aspects of viral infection and lysis in the harmful brown tide alga Aureococcus anophagefferens
}

\author{
Christopher J. Gobler ${ }^{1, *}$, O. Roger Anderson², Mary Downes Gastrich ${ }^{2}$, \\ Steven W. Wilhelm ${ }^{3}$

\begin{abstract}
${ }^{1}$ Marine Sciences Research Center, Stony Brook University, Southampton, New York 11968, USA
${ }^{2}$ Lamont-Doherty Earth Observatory of Columbia University, 61 Route 9W, Palisades, New York 10964, USA

${ }^{3}$ Department of Microbiology, The University of Tennessee, Knoxville, Tennessee 37996, USA
\end{abstract}

\begin{abstract}
Although many bloom-forming phytoplankton are susceptible to viral lysis, the persistence of blooms of algal species that are susceptible to viral infection suggests that mechanisms prohibiting or minimizing viral infection and lysis are common. We describe the isolation of viruses capable of lysing the harmful brown tide pelagophyte Aureococcus anophagefferens and an investigation of factors which influence the susceptibility of $A$. anophagefferens cells to viral lysis. Nine strains of $A$. anophagefferens-specific viruses (AaV) were isolated from 2 New York estuaries which displayed 3-order of magnitude differences in ambient $A$. anophagefferens cell densities. The host range of $\mathrm{AaV}$ was species-specific and $\mathrm{AaV}$ was able to lyse 9 of 19 clonal A. anophagefferens cultures, suggesting that resistance to viral infection is common among these algal clones. Viral lysis of A. anophagefferens cultures was delayed at reduced light intensities, indicating that the low light conditions which prevail during blooms may reduce virally induced mortality of this alga. Some $A$. anophagefferens clones which were resistant to viral infection at $22^{\circ} \mathrm{C}$ were lysed by $\mathrm{AaV}$ at lower temperatures, suggesting that the induction of viral resistance at higher temperatures could allow the proliferation of blooms during summer months. The addition of laboratory propagated viruses to bottle-incubated bloom waters $\left(>10^{5}\right.$ cells ml$\left.^{-1}\right)$ from New York and Maryland estuaries resulted in a significant reduction in $(\mathrm{p}<0.05)$, but not complete loss of, $A$. anophagefferens densities, suggesting that a resistant sub-population survived during experiments. In summary, the results demonstrate that clonal resistance, combined with the lower light levels and higher temperatures which are found during brown tides, may allow $A$. anophagefferens to form blooms during summer months.
\end{abstract}

KEY WORDS: Aureococcus anophagefferens - Algal viruses - Brown tide - Harmful algal blooms · Viral resistance $\cdot$ Viral infection $\cdot$ Strain specificity

\section{INTRODUCTION}

Harmful algal blooms (HABs) represent a significant threat to fisheries, public health, and economies around the world and have increased in frequency, duration, and distribution in recent decades. Research investigating the causes of HABs has often focused on nutrients or physical factors as stimulative causes of these events (Smayda 1990, Pitcher \& Calder 2000, Anderson et al. 2002, Sunda et al. 2006). Recently, some studies have also examined sources of mortality for blooms, such as filter feeding by zooplankton (Colin \& Dam 2002, Gobler et al. 2002) or bivalves (Ceratto et al. 2004). However, there have been substantially fewer investigations of the potential role of viruses in regulating $\mathrm{HAB}$ dynamics.

Viruses are the smallest and most abundant biological entities in the ocean and are a major cause of mortality of marine microorganisms (Wilhelm \& Suttle 1999, Suttle 2005). Species-specific lytic viruses have been described for numerous phytoplankton (e.g. Cottrell \& Suttle 1991, Suttle \& Chan 1995, Bettarel et al. 
2005) and many harmful algae (Milligan \& Cosper 1994, Nagasaki et al. 1994, Nagasaki \& Yamaguchi 1997, 1998, Lawrence et al. 2001, Tarutani et al. 2001, Nagasaki et al. 2003, Baudoux \& Brussaard 2005). Many species of HABs, particularly high biomass, ecosystem disruptive algal blooms (EDABs; Sunda et al. 2006), are known to dominate the phytoplankton communities with regard to numbers and biomass (Sunda et al. 2006). Since viruses are most likely to infect and lyse host cells when the ratio of host cells to total suspended particles is maximal (Murray \& Jackson 1992, Thingstad \& Lignell 1997), it would seem that algal viruses may be highly effective against HABs in general, and EDABs in particular, when host densities are likely to be very high. However, many HABs and EDABs bloom and persist for extended periods of time (i.e. months), without substantial population losses (Gobler et al. 2005). As such, it would seem there are multiple mechanisms, such as intraspecific variability in susceptibility to viral infection (e.g. Nagasaki \& Yamaguchi 1998, Nagasaki et al. 2003), which may prohibit viral infection and lysis of bloom populations. However, a clear understanding of these mechanisms has yet to be established.

Viruses may influence the dynamics of harmful brown tide blooms caused by the picoplanktonic, pelagophyte Aureococcus anophagefferens, which have plagued mid-Atlantic US estuaries, as well as coastal bays in South Africa (Gobler et al. 2005). Electron micrographs of the first observed brown tide event in Rhode Island and subsequent brown tides in New Jersey and New York have revealed the presence of intracellular, icosahedral virus-like particles in $A$. anophagefferens cells (Sieburth et al. 1988, Gastrich et al. 2002, 2004), suggesting that brown tide populations may experience viral infection and lysis. The densities of viruses in the water column during brown tides are elevated (Gobler et al. 2004) and field studies have observed high percentages of virally infected $A$. anophagefferens cells (40\%) during the termination of brown tides, suggesting that viruses may be an important source of mortality for blooms (Gastrich et al. 2004). A. anophagefferens-specific viruses (AaV) capable of completely lysing cultures of the brown tide alga have been previously isolated from bloom waters in New York estuaries (Milligan \& Cosper 1994). Since nothing is known about how AaV may affect brown tide population dynamics, we sought to conduct experiments examining the specificity of $\mathrm{AaV}$, as well as the degree to which light and temperature impact viral lysis of this species.

Here, we report the isolation and an ecological characterization of viruses able to infect and lyse the brown tide alga, Aureococcus anophagefferens. We isolated AaV from 2 New York estuaries and subsequently con- ducted experiments examining the susceptibility of 14 species of phytoplankton and 19 A. anophagefferens clones to lysis by these viruses. We further examined the effect of light and temperature on viral lysis of $A$. anophagefferens as well as the ability of laboratorypropagated viruses to lyse wild, bloom populations of A. anophagefferens.

\section{MATERIALS AND METHODS}

Field collection and isolation of viruses. We sampled 2 locations within the shallow (mean depth = $1.5 \mathrm{~m}$ ), well-mixed, barrier island estuaries of Long Island's south shore monthly in 2002, during the period when brown tides typically occur (April through August). Historically, Quantuck Bay (New York, $40.81^{\circ} \mathrm{N}, 72.62^{\circ} \mathrm{W}$ ) and Bay Shore Cove in western Great South Bay (New York, $40.71^{\circ} \mathrm{N}$, $73.23^{\circ} \mathrm{W}$ ) have both been subject to frequent outbreaks of brown tides caused by Aureococcus anophagefferens (Gobler et al. 2005). Carboys and experimental flasks used for this project were stored in $10 \% \mathrm{HCl}$ between sampling dates, and rinsed liberally with distilled-deionized water before use. At each field location, measurements of surface temperature and salinity were obtained with a YSI ${ }^{\odot} 85$ probe. Approximately $120 \mathrm{l}$ of surface seawater was collected in polyethylene carboys which were placed in coolers. Samples were transported to the laboratory and processed within $2 \mathrm{~h}$ of collection. Whole water was processed to determine concentrations of chlorophyll $a_{\text {, }}$ and $A$. anophagefferens and viruses at each field station. Chlorophyll samples collected on GFF glass fiber filters were analyzed via standard fluorometric methods (Parsons et al. 1984). A. anophagefferens concentrations in samples preserved in $1 \%$ glutaraldehyde were enumerated using an enzyme-linked immunoabsorbant assay (ELISA)-based monoclonal antibody labeling technique (Caron et al. 2003). The monoclonal antibody labeling technique was performed using 96-well microtiter plates and converted to abundance using a preserved culture of $A$. anophagefferens. Plates held multiple samples as well as selected dilutions of the samples. Preserved cultures (CCMP 1708) were enumerated microscopically to obtain standard curves. No significant cross-reactions have been observed with a wide variety of co-occurring algae and accurate abundances of $A$. anophagefferens can be obtained to a lower threshold concentration of approximately $10^{3}$ cells $\mathrm{ml}^{-1}$.

Viruses in $1 \%$ glutaraldehyde-preserved seawater were enumerated by epifluorescence microscopy. Specifically, $800 \mu$ l aliquots of diluted (8- to 16 -fold) sample were collected onto $25 \mathrm{~mm}$ diameter, $0.02 \mu \mathrm{m}$ 
nominal pore-size Anodisc filters (Whatman) and stained with SYBR Green 1 (Noble \& Fuhrman 1998). Viruses in these samples were enumerated manually using a Leica DMRXA epifluorescent microscope equipped with an appropriate optical filter set (excitation wavelength $=450$ to $490 \mathrm{~nm}$; emission wavelength $=510 \mathrm{~nm}$ ) and a $10 \times 10$ ocular grid (calibrated using a stage micrometer). For all samples, 20 full grids or 200 particles were enumerated to ensure statistical accuracy. These counts provided an estimate of 'total viruslike particles' in samples, of which AaV was likely a small fraction.

To isolate Aureococcus anophagefferens-specific viruses, seawater was filtered $(0.2 \mu \mathrm{m})$ with acidcleaned polypropylene filter capsules $(0.2 \mu \mathrm{m}$ pore size; MSI) and acid-washed Teflon tubing (Gobler \& Sañudo-Wilhelmy 2001). The viral size fraction (30 kDa to $0.2 \mu \mathrm{m}$ ) was subsequently concentrated 50- to 100 fold with an Amicon M12 ultrafiltration system equipped with a S10-Y30 cartridge (30 kDa mixed cellulose membrane; Wilhelm \& Poorvin 2001) and then post-filtered $(0.2 \mu \mathrm{m}$; $\mathrm{GV}$ low protein binding filter from Millipore) to ensure the removal of bacteria. A fraction of this volume was microwave sterilized (brought to near-boil and then cooled 3 times) to kill viruses, leaving 2 stocks of viral concentrate: 1 active and 1 inactivated. To screen for the presence of $A$. anophagefferens-specific viruses $(\mathrm{AaV})$ these concentrates were added to $A$. anophagefferens cultures in exponential phase growth.

Cultures of Aureococcus anophagefferens used to isolate viruses comprised Clone CCMP 1784, originally isolated from Great South Bay, Long Island, New York in 1986 (Cosper et al. 1987) and previously shown to be susceptible to viral infection and lysis (Milligan \& Cosper 1994, Gobler et al. 1997). CCMP 1784 and all phytoplankton clones used for this, and other aspects of this study, were obtained from the Provasoli-Guillard Center for Culture of Marine Phytoplankton (CCMP; http://ccmp.bigelow.org). While maintained as unialgal cultures, most cultures were not axenic when received (see Table 1). Epifluorescent microscopic inspection of DAPI-stained preparations confirmed that bacterial abundances in cultures usually remained lower than those of algae until late stationary phase. All cultures were grown in a modified $f / 2$ medium (Guillard \& Ryther 1962). Maintenance medium was prepared from filtered $(0.2 \mu \mathrm{m}$ filter capsule, Pall) Atlantic Ocean seawater collected $8 \mathrm{~km}$ southeast of the Shinnecock Inlet, near the east end of Long Island, New York and had a salinity of $\sim 30$ psu. Media modifications included the addition of $10^{-8} \mathrm{M}$ selenium as selenite, using citric acid $\left(5 \times 10^{-6} \mathrm{M}\right)$ instead of EDTA as a chelator, and using Fe concentrations of $10^{-6} \mathrm{M}$ (Cosper et al. 1993). Semi-complete medium was autoclaved for 45 min and filter-sterilized vitamins were added aseptically after cooling. Cultures were maintained at $22^{\circ} \mathrm{C}$ on a $14: 10 \mathrm{~h}$ light:dark cycle, illuminated by a bank of fluorescent lights that provided $\sim 100 \mu \mathrm{mol}$ quanta $\mathrm{m}^{-2} \mathrm{~s}^{-1}$ to cultures. These conditions approximated temperature and photoperiods found in Long Island estuaries during early summer months when $A$. anophagefferens blooms (Cosper et al. 1989, Milligan \& Cosper 1997). Light exposures were close to saturating irradiances determined for $A$. anophagefferens cultures $\left(\sim 120 \mu \mathrm{mol}\right.$ quanta $\mathrm{m}^{-2} \mathrm{~s}^{-1}$; Milligan \& Cosper 1997).

Active and inactivated field isolated virus concentrates were added to exponentially growing Aureococcus anophagefferens cultures $\left(\sim 5 \times 10^{5}\right.$ cells ml ${ }^{-1}$ initial density) as $10 \%$ of culture volume within $24 \mathrm{~h}$ of field isolation. Algal biomass was monitored daily using in vivo fluorescence (on a Turner Designs TD-700 fluorometer) and samples were preserved daily with Lugol's iodine and later enumerated with a hemacytometer on a compound light microscope. Cultures treated with active viral concentrate (which yielded a decrease in biomass while parallel control cultures grew exponentially) were suspected of being infected and lysed by A. anophagefferens-specific viruses (AaV). These cultures were filtered through $0.2 \mu \mathrm{m}$ low-protein binding filters (GV from Millipore), diluted between 1:10 ${ }^{6}$ and $1: 10^{9}$, and reinoculated into $A$. anophagefferens cultures (Strain CCMP 1784). Following a second lytic event, these cultures were filtered through $0.1 \mu \mathrm{m}$ lowprotein binding filters, and inoculated into Clone CCMP 1784 as $10 \%$ of culture volume. This process was repeated 10 times before samples were prepared for transmission electron microscopy (TEM) and before experimental work with the viral isolates was conducted.

For TEM analysis, duplicate culture samples were pre-fixed in a $2 \%$ research TEM-grade buffered $(0.2 \mathrm{M}$ cacodylate, $\mathrm{pH}=7.8$ ) glutaraldehyde solution. Samples were post-fixed in $2 \%$ osmium tetroxide $(0.2 \mathrm{M}$ cacodylate, $\mathrm{pH}=7.8$ ), dehydrated in a graded series of acetone and embedded in epon. Ultrathin sections, obtained with a diamond knife, were collected on copper grids every 50 to 100 sections to prevent duplication of observations, post-stained with Reynold's lead citrate and examined with a Philips TEM 201 electron microscope. Individual cells were examined individually in each sample for the presence of virus-like particles (VLPs) using methods previously described by Gastrich et al. (2002).

Host specificity experiments. For all experiments, an active virus sample was collected from previously infected Aureococcus anophagefferens cultures (Clones 1784 or $1984 ; \sim 5 \times 10^{5}$ cells $\mathrm{ml}^{-1}$ initial density) which had been lysed by viruses to a density of $<10^{4}$ 
cells $\mathrm{ml}^{-1}$. Lysed cultures were filtered through Millipore $0.2 \mu \mathrm{m}$, low protein binding filters (GV). This active virus filtrate was used within $24 \mathrm{~h}$ of collection to infect experimental cultures. Separate aliquots of the filtered viral lysate were heat-killed (see above) and inoculated into parallel control cultures. Active and inactivated viral lysate were added to triplicate labeled infected and control cultures at $10 \%$ of the total experimental volume. Microscopic quantification of viruses indicated that initial starting concentrations were $\sim 1 \times$ $10^{8} \mathrm{ml}^{-1}$. Biomass in the experimental and control cultures during experiments were monitored as described above. Each negative experiment was repeated at least 3 times to confirm results. Following putative viral lysis of any algal clone, cultures were filtered through $0.2 \mu \mathrm{m}$ low-protein binding filters (Type GV, Millipore), and reinnocluated into the same clone as $10 \%$ of culture volume. This process was repeated at least 3 times to confirm results.

Effects of light and temperature on virus-mediated lysis of Aureococcus anophagefferens. To determine the extent to which light levels may impact the lysis of $A$. anophagefferens by $\mathrm{AaV}$, cultures were grown at saturating irradiance $\left(110 \mu \mathrm{mol}\right.$ quanta $\mathrm{m}^{-2} \mathrm{~s}^{-1}$; Milligan \& Cosper 1997) as well as at $\sim 3 \mu \mathrm{mol}$ quanta $\mathrm{m}^{-2}$ $\mathrm{s}^{-1}$, which is below the half-saturation irradiance $\left(K_{\mathrm{lt}}\right)$ for $A$. anophagefferens cultures (69 $\mu \mathrm{mol}$ quanta $\mathrm{m}^{-2}$ $\mathrm{s}^{-1}$; Milligan \& Cosper 1997) but similar to the $K_{\text {lt }}$ observed in field blooms (1.1 to $12.8 \mu \mathrm{mol}$ quanta $\mathrm{m}^{-2}$ $\mathrm{s}^{-1}$; Lomas et al. 1996). Since host specificity experiments failed to show differences among $\mathrm{AaV}$ isolates, experiments at different irradiance values (and other subsequent experiments) were conducted exclusively using viral strain Q711 and A. anophagefferens clone CCMP 1784. Freshly harvested $(<24 \mathrm{~h}$ post-lysis) AaV were added as $10 \%$ of culture volume to exponentially growing $A$. anophagefferens cultures which began at 5 $\times 10^{5}$ cells $\mathrm{ml}^{-1}$. Cultures were monitored daily for fluorescence and cell density as described above. In addition, the maximum quantum efficiency of Photosystem II (PSII) was estimated from in vivo $\left(F_{\mathrm{o}}\right)$ and DCMU (3,4-dichlorophenyl-1,1-dimethylurea)-enhanced in vivo fluorescence $\left(F_{\mathrm{DCMU}}\right)$ of experimental samples (Parkhill et al. 2001). To avoid diel variations in these estimates, both of these fluorescence characteristics were measured at or close to the same time each day. For this procedure, sub-samples of cultures were darkadapted for $30 \mathrm{~min}$, mixed, and measured on a TD-700 Turner Designs fluorometer (Kobler et al. 1988, Parkhill et al. 2001). DCMU (in ethanol) was added (final concentration $=10 \mu \mathrm{M}$ ) to samples which were then mixed and measured again fluorometrically once this reading stabilized (approximately $30 \mathrm{~s}$ ). Maximum quantum efficiency of PSII $\left(F_{\mathrm{v}} / F_{\mathrm{m}}\right)$ was calculated using:

$$
F_{\mathrm{v}} / F_{\mathrm{m}}=\left(F_{\mathrm{DCMU}}-F_{\mathrm{o}}\right) / F_{\mathrm{DCMU}}
$$

All readings were blank corrected using $0.2 \mu \mathrm{m}$ filtered seawater from experimental bottles. DCMU blocks electron transfer between PSII and PSI and yields maximal fluorescence. Previous studies have demonstrated that $F_{\mathrm{v}} / F_{\mathrm{m}}$ can be a sensitive diagnostic of photosynthetic efficiency, reaching a maximal value of $\sim 0.7$ under nutrient-replete conditions, and decreasing to less than half of that under photosynthetic stress (Kobler et al. 1988, Parkhill et al. 2001).

To elucidate the impact of temperature on the lysis of Aureococcus anophagefferens by $\mathrm{AaV}$, selected $\mathrm{A}$. anophagefferens clones, which were both susceptible (CCMP 1784, 1851) and resistant (CCMP 1707, 1847, 1854) to viral lysis at $22^{\circ} \mathrm{C}$, were grown for 4 generations at temperatures of $5,10,15,20$ and $22^{\circ} \mathrm{C}$. A. anophagefferens does not grow at temperatures above $25^{\circ} \mathrm{C}$ (Cosper et al. 1989; this study, data not shown). Freshly harvested (<24 h post-lysis) viruses (Strain Q711) were added as $10 \%$ of culture volume to exponentially growing cultures at $\sim 5 \times 10^{5}$ cells ml $^{-1}$. Cultures were monitored daily for fluorescence and cell density as described above. To quantify the density of bacteria within some $A$. anophagefferens cultures during these experiments, samples of cultures were preserved with $2 \%$ borax-buffer formaldehyde and bacterial concentrations were determined using epifluorescence microscopy after DAPI staining (Porter \& Feig 1980).

Field experiments. To evaluate the ability of laboratory propagated AaV to influence the dynamics of wild blooms of Aureococcus anophagefferens, viral addition experiments were established. In 2002, experiments were conducted in late September using water collected from Quantuck Bay, New York (see description in subsection 'Field collection and isolation of viruses' above). Five parallel experiments were set up, one for each viral strain which was isolated from Quantuck Bay in 2002 (Table 1). For each experiment, $5 \mathrm{ml}$ of freshly isolated AaV (see above) was added to $45 \mathrm{ml}$ of bay water in triplicate, polycarbonate, $50 \mathrm{ml}$ flasks. Triplicate heat-killed controls were also established for each viral strain. To ensure nitrogen- and phosphorus-replete growth during incubations, a filter-sterilized $(0.2 \mu \mathrm{m})$ nutrient solution was added to all flasks to yield final concentrations of $20 \mu \mathrm{M}$ nitrate and $1.25 \mu \mathrm{M}$ orthophosphate. Experimental flasks were incubated for $72 \mathrm{~h}$, under 2 layers of neutral density screening (66\% light attenuation), in eastern Shinnecock Bay at the Stony BrookSouthampton Marine Station (5 km from and contiguous with Quantuck Bay), allowing for simulation of ambient light and temperature conditions of Quantuck Bay during experiments (Gobler et al. 2002). 
Table 1. Physical and biological conditions in Quantuck Bay and Great South Bay, concentration factor (CF) used to isolate viruses, success of isolating Aureococcus anophagefferens-specific viruses ( $\mathrm{AaV}$ isolated), and $\mathrm{AaV}$ strain isolated. S: salinity; Chl a: chlorophyll $a$; Cells: A. anophagefferens cells; + : AaV isolated on a given date; -: AaV not successfully isolated. Data are means $( \pm \mathrm{SD}, \mathrm{n}=3)$

\begin{tabular}{|lcccccccc|}
\hline $\begin{array}{l}\text { Date } \\
(2002)\end{array}$ & $\left.\begin{array}{c}\mathrm{T} \\
\left({ }^{\circ} \mathrm{C}\right)\end{array}\right) \mathrm{S}$ \\
$(\mathrm{psu})$ & $\begin{array}{c}\mathrm{Chl} a \\
\left(\mu \mathrm{g} \mathrm{l}^{-1}\right)\end{array}$ & $\begin{array}{c}\text { Cells } \\
\left(\mathrm{ml}^{-1} \times 10^{3}\right)\end{array}$ & $\begin{array}{c}\text { Viruses } \\
\left(\mathrm{ml}^{-1} \times 10^{8}\right)\end{array}$ & $\begin{array}{c}\mathrm{CF} \\
\text { AaV } \\
\text { isolated }\end{array}$ & $\begin{array}{c}\text { AaV } \\
\text { strain }\end{array}$ \\
\hline Quantuck Bay & & & & & & \\
19 Apr & 20 & 29 & $18 \pm 0.96$ & $10 \pm 3.5$ & $2.6 \pm 0.71$ & 120 & - & - \\
23 May & 16 & 28 & $5.5 \pm 0.73$ & $37 \pm 1.5$ & $1.0 \pm 0.19$ & 100 & + & Q523 \\
04 Jun & 20 & 29 & $9.8 \pm 3.3$ & $68 \pm 1.9$ & $1.6 \pm 0.471$ & 80 & + & Q64 \\
18 Jun & 21 & 26 & $19 \pm 3.0$ & $870 \pm 36$ & $3.8 \pm 1.3$ & 100 & + & Q618 \\
11 Jul & 24 & 30 & $30 \pm 5.0$ & $110 \pm 19$ & $3.9 \pm 0.92$ & 100 & + & Q711 \\
08 Aug & 24 & 29 & $21.5 \pm 3.2$ & $19 \pm 0.55$ & $1.6 \pm 0.14$ & 100 & + & Q88 \\
Great South Bay & & & & & & \\
24 Apr & 14 & 29 & $5.3 \pm 0.66$ & $1.5 \pm 0.27$ & $0.66 \pm 0.12$ & 40 & - & - \\
21 May & 16 & 27 & $5.3 \pm 1.3$ & $18 \pm 0.82$ & $1.3 \pm 0.45$ & 95 & + & B512 \\
06 Jun & 22 & 27 & $7.1 \pm 1.6$ & $10 \pm 0.27$ & $1.6 \pm 0.76$ & 95 & + & B66 \\
20 Jun & 23 & 28 & $4.6 \pm 2.1$ & $17 \pm 2.4$ & $2.2 \pm 0.15$ & 105 & + & B620 \\
09 Jul & 26 & 29 & $4.5 \pm 0.79$ & $4.3 \pm 2.0$ & $0.79 \pm 0.28$ & 90 & + & B79 \\
06 Aug & 28 & 30 & $5.6 \pm 0.66$ & $5.0 \pm 0.27$ & $0.66 \pm 0.16$ & 110 & - & - \\
\hline
\end{tabular}

\section{RESULTS}

\section{Initial isolation and propagation of $\mathrm{AaV}$}

Great South Bay and Quantuck Bay differed in their respective algal and viral densities during 2002, with Quantuck hosting significantly higher levels of chlorophyll a ( $\mathrm{chl} \mathrm{a)} \mathrm{(mean} \pm$ $\mathrm{SE}=17 \pm 3.5 \mu \mathrm{g} \mathrm{l}^{-1}$ ), Aureococcus anophagefferens cell densities $(1.8 \pm$ $1.3 \times 10^{5}$ cells ml $\left.{ }^{-1}\right)$, and total VLPs (2.4 $\pm 0.5 \times 10^{8} \mathrm{ml}^{-1}$ ) compared to Great

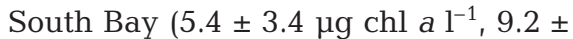
$2.8 \times 10^{3} \mathrm{~A}$. anophagefferens cells $\mathrm{ml}^{-1}$, and $1.2 \pm 0.3 \times 10^{8} \mathrm{VLPs} \mathrm{m}{ }^{-1}$; Table $1 ; \mathrm{p}<0.05$ for all; $t$-tests). Despite these differences, there was near equal success in isolating $A$. anophagefferens-specific viruses (AaV) from the 2 sites, as viruses were iso-

After $72 \mathrm{~h}$, aliquots from each flask were removed, preserved and enumerated for densities of $A$. anophagefferens (see description in subsection 'Field collection and isolation of viruses'). Differences in $A$. anophagefferens cell densities within each active and inactivated virus strain addition were evaluated via a Student's $t$-test (Sokal \& Rohlf 1995).

During June of 2003, an experiment was conducted in Public Landing, Chincoteague Bay, Maryland $\left(38.15^{\circ} \mathrm{N}, 75.29^{\circ} \mathrm{W}\right)$ which has experienced frequent and intense brown tides during the past decade (Gobler et al. 2005). For this experiment, there were 3 sets of triplicate flasks: A nutrient only control (nutrients, but no viruses, added), an active viral addition (with nutrients added), and an inactivated viral addition (with nutrients added). Virus additions were $25 \mathrm{ml}$ of freshly propagated and filtered AaV Strain Q711 which was unamended or heat-killed, and added to $225 \mathrm{ml}$ of bay water in $275 \mathrm{ml}$ polycarbonate flasks. All flasks had nutrients added as described above. Flasks were incubated in situ in Public Landing under 2 layers of neutral density screening $(66 \%$ light attenuation), allowing for simulation of ambient light and temperature conditions. After $72 \mathrm{~h}$, aliquots from each flask were removed, preserved and enumerated for densities of Aureococcus anophagefferens (see description in subsection 'Field collection and isolation of viruses'). Differences in A. anophagefferens cell densities within active, inactivated, and control treatments during the Chincoteague Bay experiment were evaluated by 1-way ANOVA, followed by Tukey's multiple comparisons test (Sokal \& Rohlf 1995). lated from Quantuck Bay on 5 of 6 dates, and from Great South Bay on 4 of 6 dates (Table 1). Viruses were not isolated from either site in April, and none were isolated during August in Great South Bay.

There were multiple lines of evidence to confirm the isolation of $\mathrm{AaV}$ from each embayment. After the addition of active viral concentrate from the field, Aureococcus anophagefferens cultures did not grow and decreased to undetectable cell densities in less than 1 wk (Fig. 1). By contrast, the heat-killed viral concen-

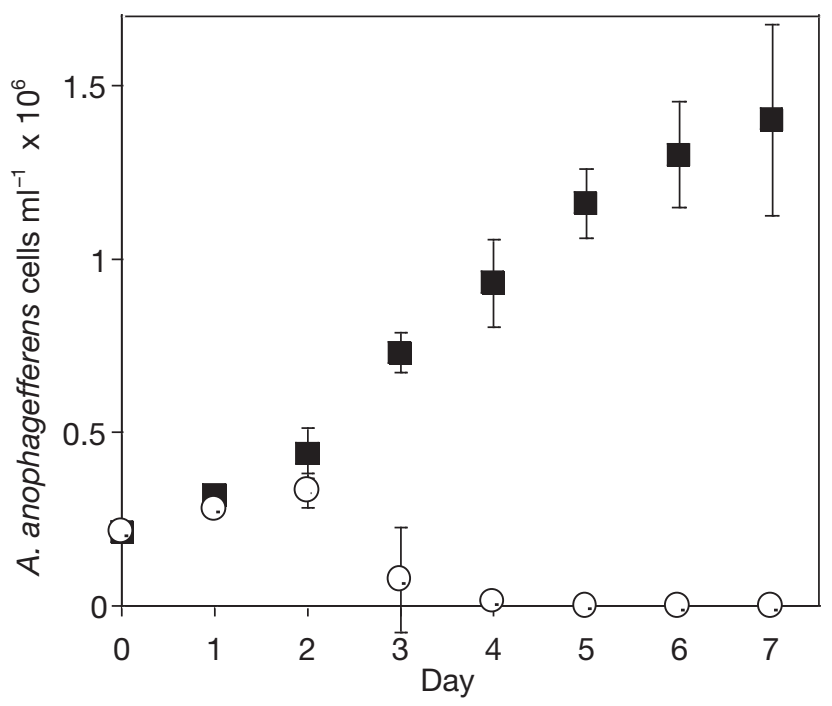

Fig. 1. Aureococcus anophagefferens. Mean $( \pm \mathrm{SD}, \mathrm{n}=3)$ growth of clone CCMP 1784 following addition of heat-killed (ם) and active (O) viral concentrates isolated from Quantuck Bay in 2002 
trate fostered standard logarithmic growth in A. anophagefferens cultures (Fig. 1). Following putative viral lysis of an $A$. anophagefferens culture, viral filtrate of lysed cultures were filtered through $0.1 \mu \mathrm{m}$ filters, diluted between $1: 10^{6}$ and $1: 10^{9}$, and reinoculated in $A$. anophagefferens cultures. This yielded the complete loss of cells from cultures in the lower dilutions (e.g. Fig. 1). After propagation of culture filtrate through $A$. anophagefferens cultures for 10 generations, TEMs of cultures infected with viruses at $48 \mathrm{~h}$ displayed inclusions of virus-like particles which were nearly identical to those previously reported for wild blooms (Fig. 2A; Sieburth et al. 1988, Gastrich et al. 2002, 2004) and laboratory cultures (Gastrich et al. 1998). Moreover, individual VLPs external to the cells observed with TEM resembled the morphology and size of those in the cells (Fig. 2B).

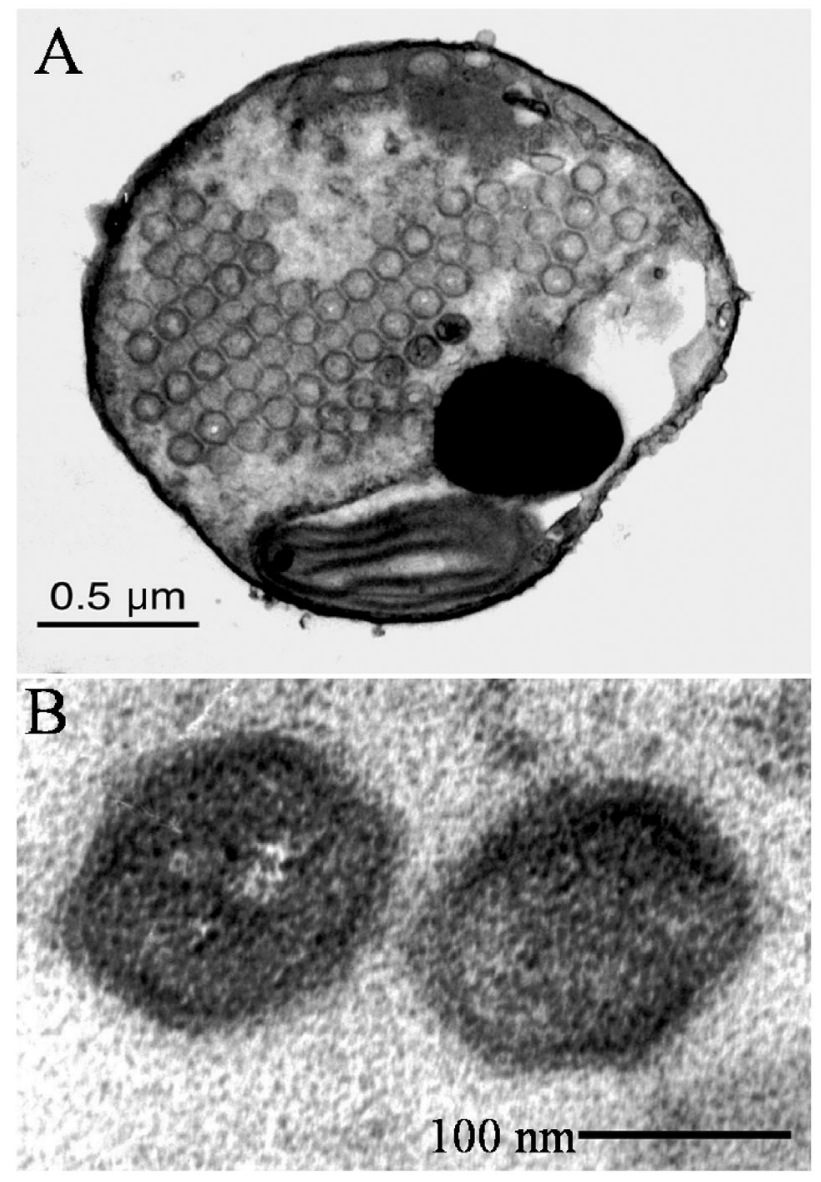

Fig. 2. Aureococcus anophagefferens. Clone CCMP 1984. Thin-section transmission electron micrographs (A) $48 \mathrm{~h}$ after addition of $0.1 \mu \mathrm{m}$ filtrate from putatively lysed culture, and (B) showing putative $A$. anophagefferens-specific virus (AaV) external to cells co-occurring within culture. Both micrographs show AaV Clone Q711

\section{Host range of $\mathrm{AaV}$}

Each of the 9 lines of viruses was propagated through the axenic Aureococcus anophagefferens strain CCMP 1984 for 6 mo and was subsequently used to establish the host range of the viruses. None of the 9 strains of $\mathrm{AaV}$ was capable of lysing any of the 14 phytoplankton tested besides $A$. anophagefferens (Table 2), including the 3 pelagophytes available from CCMP: Pelagomonas spp. (CCMP 1864), Pelagococcus subviridis (CCMP 1429) and Aureoumbra lagunensis (CCMP 1681; Table 2). Of the 19 clones of Aureococcus anophagefferens available from CCMP, 7 were completely lysed by the 9 strains of viruses isolated in 2002, including both axenic clones (CCMP 1982, 1984; Table 2). Two of the A. anophagefferens clones (CCMP 1850 and 1852) were partially, but not fully, lysable by $\mathrm{AaV}$, typically displaying at least a $50 \%$ reduction in, but not full loss of, algal biomass relative to control cultures within 1 wk of viral inoculation (Table 2). TEM analysis indicated that these 2 strains showed a significantly lower percentage of infected cells 2 d after inoculation with viruses $(1.5 \pm 0.7 \%)$ compared to a fully lysable culture (CCMP 1851; $44 \pm 18 \%$; $t$-test; $\mathrm{p}<$ 0.05). Moreover, an extended incubation of one of these cultures (>1 mo; CCMP 1850) yielded a recovery in cell densities to levels beyond the initial inoculation. These 'recovered' cultures were not subsequently susceptible to lysis by AaV. There was no variability in the ability of the 9 different isolated viral strains (Table 1) to infect different clones of $A$. anophagefferens.

\section{Impact of reduced light levels on viral lysis of Aureococcus anophagefferens}

Replicated incubations of Aureococcus anophagefferens at high and low light levels demonstrated that cultures incubated at lower light levels experienced a delay in viral lysis compared to cultures incubated at high light (Fig. 3). A. anophagefferens cultures inoculated with viruses incubated under high light conditions $\left(110 \mu \mathrm{mol}\right.$ quanta $\left.\mathrm{m}^{-2} \mathrm{~s}^{-1}\right)$ typically lysed within $3 \mathrm{~d}$, reaching cell densities $<10^{4}$ cells $\mathrm{ml}^{-1}$ (Fig. 3). Control cultures grown under low light $(\sim 3 \mu \mathrm{mol}$ quanta $\mathrm{m}^{-2} \mathrm{~s}^{-1}$ ) did not change appreciably in cell densities, while those inoculated with viruses took $7 \mathrm{~d}$ to decrease below $10^{4}$ cells $\mathrm{ml}^{-1}$ (Fig. 3A). During experiments, the photosynthetic efficiency of all cultures was $0.48 \pm 0.06$ at the beginning and increased to $\sim 0.6$ within $24 \mathrm{~h}$ of inoculation into new media, regardless of light levels (Fig. 3B). After this initial increase, photosynthetic efficiency of non-infected cultures at high and low light decreased each day until the end of the experiment (Fig. 3B). In contrast, 
Table 2. Host-specificity of Aureococcus anophagefferens viruses (AaV). CCMP: Provasoli-Guillard Center for Culture of Marine Phytoplankton. Origin, isolation date, and axenic condition all refer to host phytoplankton. Lysis denotes ability of AaV to infect and lyse each species or strain

\begin{tabular}{|c|c|c|c|c|c|c|}
\hline Genus, species & Algal class & CCMP clone & Origin & Isolation date & Axenic & Lysis \\
\hline Phaeodactylum tricornutum & Bacillariophyceae & 630 & Cape Cod Bay, MA & 1972 & Yes & No \\
\hline Dunaliella tertiolecta & Chlorophyceae & 1320 & Unknown & Unknown & Yes & No \\
\hline Thalassiosira pseudonana & Coscinodiscophyceae & 1335 & Moriches Bay, NY & Sep 1958 & Yes & No \\
\hline Rhodomonas salina & Cryptophyceae & 1319 & Long Island Sound, NY & 1956 & No & No \\
\hline Prorocentrum minimum & Dinophyceae & 696 & Great South Bay, NY & 1985 & No & No \\
\hline Synechococcus bacillaris & Cyanophyceae & 1333 & Long Island Sound, NY & 1958 & No & No \\
\hline Emiliania huxleyi & Prymnesiophyceae & 375 & Sargasso Sea & 1967 & No & No \\
\hline Pycnococcus provasolii & Prasinophyceae & 1203 & Northwest Atlantic & 1978 & No & No \\
\hline Tetraselmis sp. & Prasinophyceae & 896 & Falmouth Great Pond, MA & 1954 & Yes & No \\
\hline Chlorella autotrophica & Trebouxiophyceae & 243 & Long Island Sound, NY & 1952 & Yes & No \\
\hline Nannochloris atomus & Trebouxiophyceae & 509 & Great South Bay, NY & 1952 & Yes & No \\
\hline Pelagomonas sp. & Pelagophyceae & 1864 & Sargasso Sea & 1999 & No & No \\
\hline Pelagococcus subviridis & Pelagophyceae & 1429 & Baltic Sea & Unknown & Yes & No \\
\hline Aureoumbra lagunensis & Pelagophyceae & 1681 & Laguna Madre, TX & 1991 & No & No \\
\hline Aureococcus anophagefferens & Pelagophyceae & 1706 & West Neck Bay, NY & Oct 1995 & No & No \\
\hline Aureococcus anophagefferens & Pelagophyceae & 1707 & West Neck Bay, NY & Oct 1995 & No & No \\
\hline Aureococcus anophagefferens & Pelagophyceae & 1708 & West Neck Bay, NY & Jun 1995 & No & Yes \\
\hline Aureococcus anophagefferens & Pelagophyceae & 1784 & Great South Bay, NY & Jun 1986 & No & Yes \\
\hline Aureococcus anophagefferens & Pelagophyceae & 1785 & Great South Bay, NY & Jun 1986 & No & Yes \\
\hline Aureococcus anophagefferens & Pelagophyceae & 1789 & Great South Bay, NY & Oct 1995 & No & No \\
\hline Aureococcus anophagefferens & Pelagophyceae & 1790 & Great South Bay, NY & Oct 1995 & No & No \\
\hline Aureococcus anophagefferens & Pelagophyceae & 1791 & Great South Bay, NY & Oct 1995 & No & No \\
\hline Aureococcus anophagefferens & Pelagophyceae & 1794 & Barnegat Bay, NJ & Jul 1997 & No & Yes \\
\hline Aureococcus anophagefferens & Pelagophyceae & 1847 & Great South Bay, NY & May 1998 & No & No \\
\hline Aureococcus anophagefferens & Pelagophyceae & 1848 & Great South Bay, NY & May 1998 & No & No \\
\hline Aureococcus anophagefferens & Pelagophyceae & 1849 & Great South Bay, NY & May 1998 & No & No \\
\hline Aureococcus anophagefferens & Pelagophyceae & 1850 & Great South Bay, NY & May 1998 & No & Partial \\
\hline Aureococcus anophagefferens & Pelagophyceae & 1851 & Great South Bay, NY & May 1998 & No & Yes \\
\hline Aureococcus anophagefferens & Pelagophyceae & 1852 & Great South Bay, NY & May 1998 & No & Partial \\
\hline Aureococcus anophagefferens & Pelagophyceae & 1853 & Great South Bay, NY & May 1998 & No & No \\
\hline Aureococcus anophagefferens & Pelagophyceae & 1854 & Great South Bay, NY & May 1998 & No & No \\
\hline Aureococcus anophagefferens & Pelagophyceae & 1982 & Great South Bay, NY & Jun 1986 & Yes & Yes \\
\hline Aureococcus anophagefferens & Pelagophyceae & 1984 & Great South Bay, NY & Jun 1986 & Yes & Yes \\
\hline
\end{tabular}

high light infected cultures displayed a significant increase in photosynthetic efficiency compared to the higher light control on Days 2 and 3 (ANOVA, p < 0.05 ; Fig. 3B), whereas low light cultures displayed higher photosynthetic efficiency compared to their control cultures on Days 4 and 5 (ANOVA, p $<0.05$; Fig. 3B). By the end of the experiment, the photosynthetic efficiency of both infected cultures had decreased substantially, becoming lower than control cultures (Fig. 3B).

Fig. 3. Aureococcus anophagefferens. Clone CCMP 1784. (A) Cell concentrations and (B) photosynthetic efficiency of cultures grown at high light with active (O) and heat-killed $(\square)$ viruses and at low light with active $(\bullet)$ and heat-killed (ם) viruses (means $\pm \mathrm{SD}, \mathrm{n}=3$ ). Heat-killed viral control in (A) grew in similar manner to the same treatment in Fig. 1, but was cut off to maintain higher resolution of the other treatments
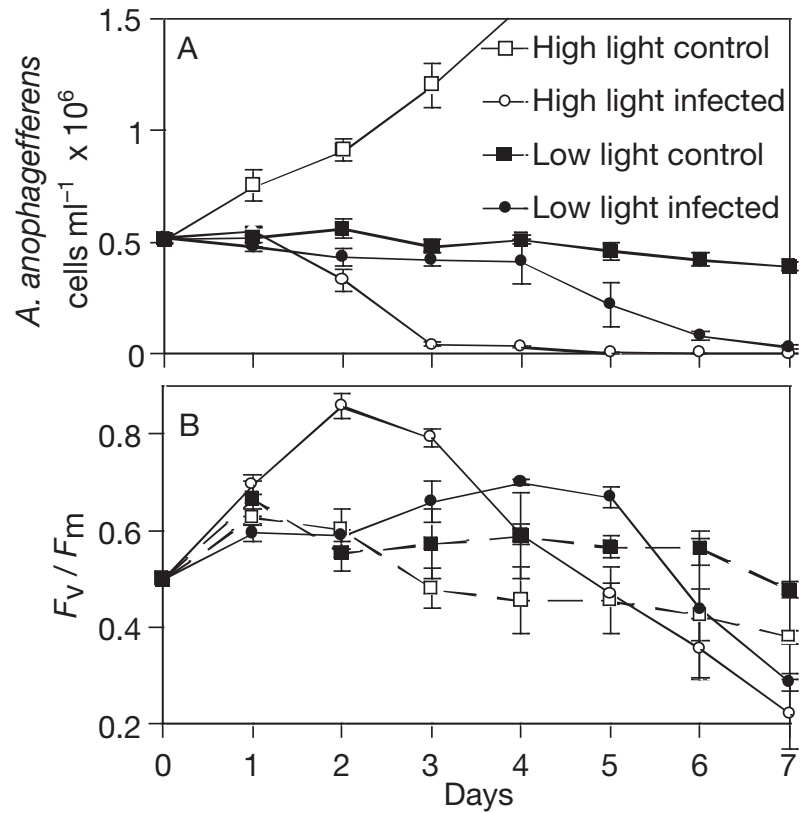


\section{Impact of temperature on viral lysis of Aureococcus anophagefferens}

Temperature had a substantial impact on the ability of AaV to lyse some clones of Aureococcus anophagefferens. All clones of $A$. anophagefferens examined which were susceptible to $\mathrm{AaV}$ at the standard incubation temperature $22^{\circ} \mathrm{C}$ (CCMP 1982, 1784, 1851) were equally susceptible to viral lysis over the range of temperatures examined $\left(10\right.$ to $\left.22^{\circ} \mathrm{C}\right)$. However, 2 clones of $A$. anophagefferens which were resistant to $\mathrm{AaV}$ at $22^{\circ} \mathrm{C}$ were lysed by the viruses at lower temperatures (Fig. 4). Specifically, although clones 1854 and 1707 were both resistant to viral lysis at $22^{\circ} \mathrm{C}_{\text {, }}$ clone 1854 experienced viral lysis at all incubation temperatures below $22^{\circ} \mathrm{C}$ (Fig. 4B), whereas clone 1708 was lysable at 10 and $5^{\circ} \mathrm{C}$, but not at 20 and $15^{\circ} \mathrm{C}$ (Fig. 4A). The ability of AaV to lyse other strains of $A$. anophagefferens (clones 1847 and 1850) was not affected by incubation temperature.

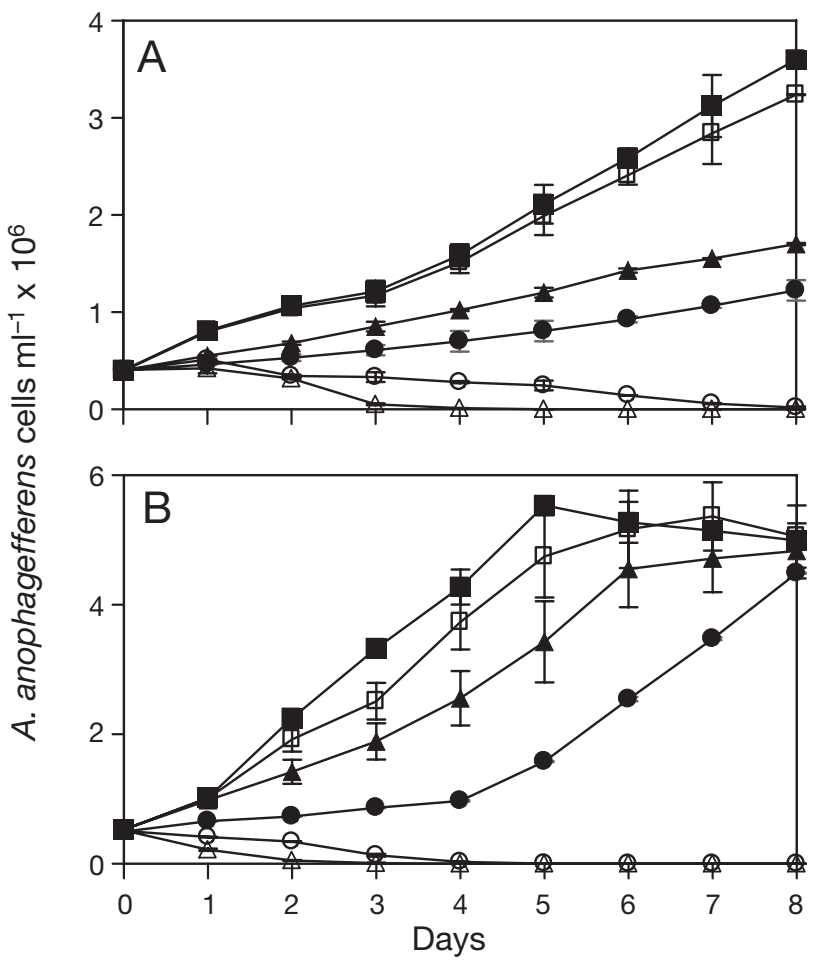

Fig. 4. Aureococcus anophagefferens. Mean $( \pm \mathrm{SD}, \mathrm{n}=3)$ cell densities of clones grown with active (open symbols) and inactive (filled symbols) cultures. (A) Clone CCMP 1707 grown at $22^{\circ} \mathrm{C}(\square, \boldsymbol{\square}), 10^{\circ} \mathrm{C}(\Delta, \boldsymbol{\Delta})$, and $5^{\circ} \mathrm{C}(\mathrm{O}, \mathbf{0})$; (B) Clone CCMP 1854 grown at $22^{\circ} \mathrm{C}(\square, \boldsymbol{\square}), 20^{\circ} \mathrm{C}(\Delta, \mathbf{\Delta})$, and $15^{\circ} \mathrm{C}$ $(\mathrm{O}, 0)$. CCMP 1707 was not lysed at 20 and $15^{\circ} \mathrm{C}$, whereas CCMP 1854 was lysed at all tested temperatures below $22^{\circ} \mathrm{C}$ $\left(20,15,10^{\circ} \mathrm{C}\right)$; only 3 temperature treatments are shown per clone for clarity

\section{Infection of natural populations of Aureococcus anophagefferens by laboratory-cultured virus}

During late September 2002, the brown tide bloom in Quantuck Bay returned and achieved densities of $5 \times$ $10^{5}$ cells ml $^{-1}$ (Table 1 ). The addition of 3 viral strains isolated from Quantuck Bay to the bloom water, contained in flasks placed in situ, did not significantly alter the densities of Aureococcus anophagefferens (Fig. 5), although there was often substantial variability among replicate treatments. However, the addition of virus strains Q618 and Q711 resulted in significant (60 and $40 \%$, respectively) decreases in A. anophagefferens cell densities compared to the heat-killed control additions ( $<<0.05 ; t$-test; Fig. 5). During June 2003, a substantial brown tide bloom occurred in Chincoteague Bay $\left(>3 \times 10^{5}\right.$ cells $\left.\mathrm{ml}^{-1}\right)$. The experimental addition of active AaV strain Q711 to this bloom water yielded $A$. anophagefferens cell densities which were significantly $(\sim 70 \%)$ lower than initial and control treatment densities ( $p<0.01$; Tukey's test; Fig. 6$)$.

\section{DISCUSSION}

While virus-mediated cell lysis is often cited as a primary mortality mechanism for marine microbes in general (Wilhelm \& Suttle 1999, Wommack \& Colwell 2000, Suttle 2005), and harmful algae in particular (Nagasaki et al. 1994, Nagasaki \& Yamaguchi 1998, Tarutani et al. 2000, 2001, Lawrence et al. 2001, Thyrhaug et al. 2003, Brussaard 2004, Gastrich et al. 2004, Zingone et al. 2006), the occurrence of algal blooms indicates that rates of viral lysis are (at least upon bloom initiation) lower than phytoplankton growth rates. During this study, the resistance of some Aureococcus anophagefferens clones at all tempera-

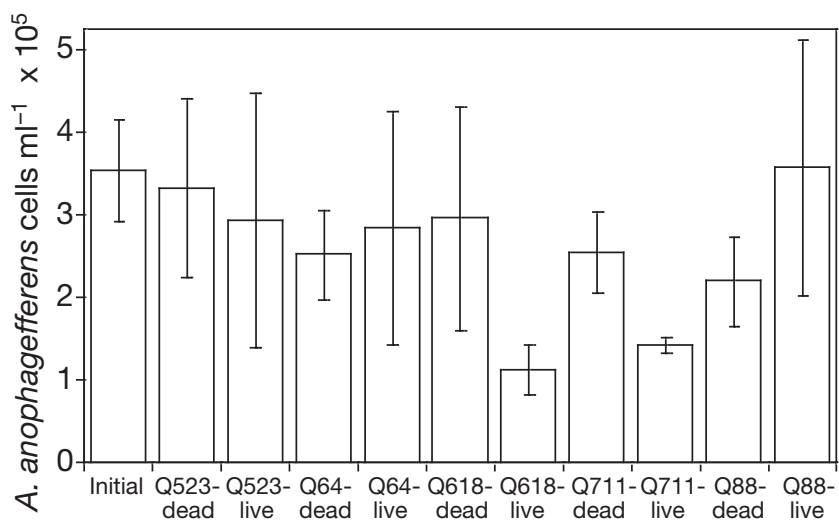

Fig. 5. Aureococcus anophagefferens. Mean $( \pm \mathrm{SD}, \mathrm{n}=3)$ initial cell densities in Quantuck Bay, September 2002, and $72 \mathrm{~h}$ after addition of active or inactivated viral isolates Q523, Q64, Q618, Q711, and Q88 


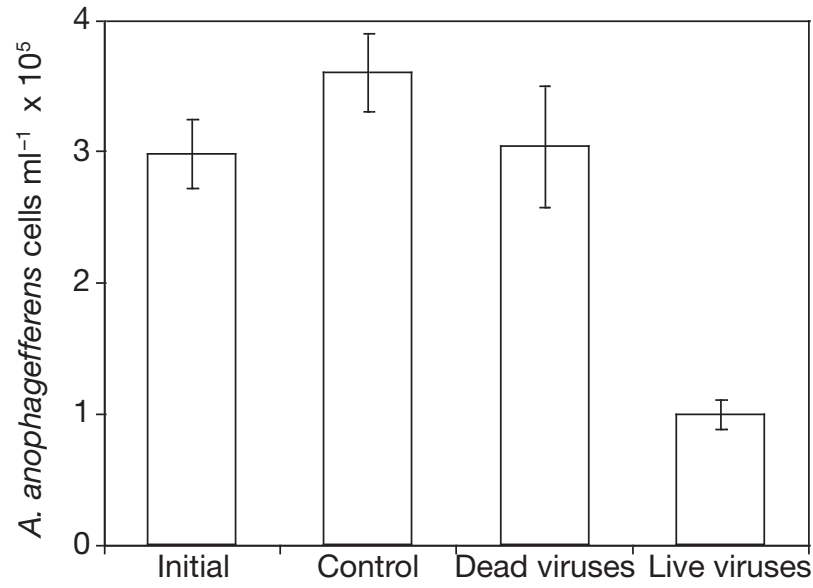

Fig. 6. Aureococcus anophagefferens. Mean $( \pm \mathrm{SD}, \mathrm{n}=3)$ initial cell densities in Chinchoteague Bay, June 2003, and $72 \mathrm{~h}$ after addition of nutrients and active or inactivated viral isolates Q711, and Q88, or nutrients only ('Control')

tures, and other clones at higher temperatures, suggests a novel mechanism whereby brown tides are likely able to progress in the absence of viral mortality. These results, combined with experiments demonstrating that viral lysis is delayed at lower light levels and with field experiments indicating that laboratory-propagated viruses can lyse a portion of, but not all, $A$. anophagefferens cells, provide a new understanding of the role of $\mathrm{AaV}$ in brown tide bloom dynamics.

To date, there has been a degree of uncertainty regarding the morphology of $\mathrm{AaV}$ as 2 distinct viral morpho-types have been reported. Intracellular viruses within field populations of Aureococcus anophagefferens (Sieburth et al. 1988; Gastrich et al. 1998, 2002, 2004) and recently isolated viruses from NY and NJ waters (Gastrich et al. 2004) have been shown to be icosahedral and 100 to $140 \mathrm{~nm}$ in diameter. In contrast, the first ever isolated $\mathrm{AaV}$ were shown to resemble $80 \mathrm{~nm}$, tailed-phages (Milligan \& Cosper 1994, Garry et al. 1998) and have since been suspected of being a bacteriophage which had infected co-occurring bacteria in $A$. anophagefferens cultures. During the present study, viruses both within and outside $A$. anophagefferens cells strongly resembled the former morphology ( 100 to $140 \mathrm{~nm}$ icosahedrals; Fig. 2) which has consistently been found within field populations of this species (Sieburth et al. 1988, Gastrich et al. 1998, 2004). Moreover, our dilution of field isolated viral concentrates to extinction, combined with the ability of our $0.1 \mu \mathrm{m}$ filtered virus lysate to infect and lyse axenic cultures, strongly implicate the action of a lytic virus on $A$. anophagefferens cells and not the action of, or interaction with, bacteria.
Although some algal viruses (specifically cyanophage) can infect multiple genera of phytoplankton (Suttle \& Chan 1993, Sullivan et al. 2003), the majority are species-, and often clone-specific (Nagasaki \& Yamaguchi 1998, Tarutani et al. 2000, Schroeder et al. 2002). This was the case with $A a V$, as these viruses were unable to infect even the alga most genetically similar to Aureococcus anophagefferens, the Texas brown tide species, Aureoumbra lagunensis (DeYoe et al. 1995). Among $A$. anophagefferens clones available, $\mathrm{AaV}$ was capable of lysing only a fraction (9) of the 19 clones available (Table 2). Prior analysis of the genetic diversity of $A$. anophagefferens revealed identical base pair sequences for the small subunit of the rRNA gene, the small subunit of the RuBISCo gene, and the non-encoding spacer regions of RuBISCo within 14 clones of $A$. anophagefferens isolated over a $12 \mathrm{yr}$ period (1986 to 1998) from 3 different estuaries (Peconic Bay, Great South Bay and Barnegat Bay) in 2 states (New York and New Jersey; Bailey \& Andersen 1999). These identical sequences led Bailey and Andersen (1999) to conclude that A. anophagefferens field populations are not genetically diverse and do not contain varieties or cryptic species. Despite these findings, our examination of viral infection of these same clones (plus 5 addition clones) has documented 3 distinct responses to viruses: susceptible to lysis, resistant to lysis and partially resistant to lysis by AaV. This could indicate that there is a larger degree of genetic diversity among $A$. anophagefferens clones than originally described (Bailey \& Andersen 1999), potentially associated with cell-surface receptor sites.

It is also possible that the ability of $\mathrm{AaV}$ to absolutely lyse some individual Aureococcus anophagefferens cultures may be influenced by the precise clonal nature of the cultures. Two of the algal clones examined during this study were partially, but not completely, lysed by AaV (Table 2), and one of these cultures (CCMP 1850) displayed robust growth several weeks after an initial decline in biomass. This result could reflect the development of resistance in culture during this experiment. Alternatively, it may also reflect the existence of both susceptible and resistant strains of $A$. anophagefferens in the same purported monoclonal culture. This hypothesis is partially supported by the low percentage of infected cells in semi-resistant cultures compared to fully susceptible cultures $(1.5 \pm 0.7$ vs. $44 \pm$ $18 \%$ ) $48 \mathrm{~h}$ after AaV was added to both culture types.

Viral lysis of Aureococcus anophagefferens is delayed at low irradiances (Fig. 3). Previous research has suggested that the energy used for host replication of algal viruses is often derived from photosynthetic pathways (MacKenzie \& Haselkorn 1972, Sherman 1976, Juneau et al. 2003, Lindell et al. 2005). As such, the delay in viral lysis of $A$. anophagefferens at lower 
light levels suggests that at least some of the energy derived for $\mathrm{AaV}$ synthesis is derived from photosynthesis. This hypothesis is supported by observation that the photosynthetic efficiency of virally infected cultures was, at times, higher than that of control cultures, regardless of light levels (Fig. 3B). Furthermore, TEM observations of viral-infected cells have consistently shown that the chloroplast of $A$. anophagefferens persists during the production of intracellular viral-like particles, even though other membranous organelles are degraded or absent (Fig. 2A; Gastrich et al. 2002, 2004), indicating potential for cells to photosynthesize, even after viral infection. However, since control cultures growing at low light and with inactivated viruses did not grow substantially, we cannot fully discount the possibility that delayed lysis under low light may be due to reduced host growth rates, rather than low light.

The link between viral lysis of Aureococcus anophagefferens and its photosynthesis has 2 important implications for the occurrence of brown tide blooms. First, since light is highly attenuated during brown tides due to scattering by high densities $\left(10^{6} \mathrm{ml}^{-1}\right)$ of these smallsized cells (2 to $3 \mu \mathrm{m}_{i}$ Gobler et al. 2005), A. anophagefferens photosynthetic rates may be reduced during blooms. If this is the case, rates of viral lysis during brown tides may decrease as blooms become denser and light levels decrease, even though some of the cells may be infected by the viruses. A second implication of the link between photosynthesis and viral lysis of brown tide is associated with the ability of $A$. anophagefferens to growth heterotrophically (Berg et al. 2002, Mullholland et al. 2002, Gobler et al. 2005). Our results suggest that a strong reliance on external organic carbon sources rather than cellular photosynthesis for growth by $A$. anophagefferens could minimize viral replication and thus mortality losses due to viral lysis during brown tides, further promoting bloom proliferation. In this respect, it is important to note, once again, that TEM has indicated that during VLP proliferation within the cell, the chondriome is degraded or absent (Fig. 2A; Gastrich et al. 2002, 2004). Hence, there is little likelihood that substantial, heterotrophic-based respiratory energy would be available to support viral particle production during advanced stages of viral infection. Indeed, most of the energy for viral production may come from chloroplast-captured light energy.

Two clones of Aureococcus anophagefferens that were resistant to viral lysis at $22^{\circ} \mathrm{C}$ were lysed by $\mathrm{AaV}$ at lower temperatures (Fig. 4). This result is somewhat consistent with the findings of Nagasaki \& Yamaguchi (1998), who also found strain-specific resistance to viral infection at higher temperature, in their case $30^{\circ} \mathrm{C}$. The observed impact of temperature on viral lysis of $A$. anophagefferens could have important implications for brown tide dynamics. A. anophagef- ferens blooms most commonly initiate during summer months in mid-Atlantic US as estuarine temperatures increase from cool spring temperatures $\left(<10^{\circ} \mathrm{C}\right)$ to $>20^{\circ} \mathrm{C}$ and often end in the fall when temperatures again fall below $20^{\circ} \mathrm{C}$ (Gobler et al. 2005). If some wild clones of $A$. anophagefferens switch from being virally susceptible to virally resistant during the warming trend of late spring and switch from resistant to susceptible during the cooling trend of autumn, it would explain the initiation and persistence of brown tides during the summer months.

The inability of AaV to lyse some clones of Aureococcus anophagefferens at higher temperatures may be associated with elevated bacterial densities at higher culture temperatures. A. anophagefferens Clone 1854 grown at $22^{\circ} \mathrm{C}$ in late exponential phase growth had twice the number of bacteria $(1.7 \pm 0.4 \times$ $\left.10^{7} \mathrm{ml}^{-1}\right)$ of parallel cultures grown at $10^{\circ} \mathrm{C}(8.4 \pm 0.2 \times$ $10^{6} \mathrm{ml}^{-1}$ ). Adsorption of viruses onto bacterial cells or bacterial cells onto host surface viral receptor sites could prohibit viral infection of $A$. anophagefferens (Rabinovitch et al. 2003, Thyrhaug et al. 2003). Alternatively, AaV could be degraded and rendered inactive by the proteolytic action of bacteria at higher densities. As such, we speculate that the presence of significantly higher bacterial densities during the periods of warmer temperatures which exist during brown tides (Gobler \& Sañudo-Wilhelmy 2003) may promote these mechanisms during bloom events.

The results of some of our field experiments suggest that laboratory-propagated $\mathrm{AaV}$ can effectively reduce densities of bloom populations of Aureococcus anophagefferens (Figs. 5 \& 6). In NY in 2002, the addition of 2 of the 5 viral strains to bloom water, contained in flasks and incubated in situ reduced densities of $A$. anophagefferens by $>60 \%$ (Fig. 5) and in MD in 2003, the addition of a single viral strain had a similar impact (Fig. 6). Preliminarily, these results might suggest that AaV could serve as a moderately effective biocontrol of brown tides (Sengco \& Anderson 2004). However, it is notable that although $A$. anophagefferens densities were significantly reduced during some of these $3 \mathrm{~d}$ experiments, $>10^{5}$ cells ml ${ }^{-1}$ remained unlysed by the end of the experiments (Figs. $5 \& 6$ ). This is more than 1 order of magnitude higher than densities found in lysable laboratory cultures $3 \mathrm{~d}$ after the addition of active AaV (Fig. 1). While some of these cells might have been lysed if the experiment had persisted longer, these remaining cells could represent a subpopulation of $A$. anophagefferens which is resistant to viral lysis (Table 2). If this were the case, this finding, taken with the resistance of many A. anophagefferens clones of $\mathrm{AaV}$, suggests that viruses may have a greater impact on the clonal diversity of brown tide populations than on their abundances. 
Acknowledgements. We thank the following Southampton College students and faculty members for assistance with this project: Danielle Thibault, Jeffery Krause, Kristen Rathjen, Jessica Jaret, Gina, Franco, George Boneillo, Juleen Dickson, Glynis Pererya, David Barrieo, Matthew Vilbas, Sarah Deonarine, Florian Koch. This research was supported, in part, by EPA Star award \#R82-9367-010. C.J.G.'s effort was also supported by by NOAA, Coastal Ocean Program ECOHAB award \#NA16OP2790. This is MSRC Contribution Number 1336, Lamont-Doherty Earth Observatory Contribution Number 7001, and ECOHAB contribution number 229.

\section{LITERATURE CITED}

Anderson DM, Glibert PM, Burkholder JM (2002) Harmful algal blooms and eutrophication: nutrient sources, composition, and consequences. Estuaries 25:704-726

Bailey CJ, Andersen RA (1999) Analysis of clonal cultures of the brown tide algae Aureococcus and Aureoumbra (Pelagophyceae) using 18S rRNA, rbcL and RUBISCO spacer sequences. J Phycol 35:570-574

Baudoux AC, Brussaard CPD (2005) Characterization of different viruses infecting the marine harmful algal bloom species Phaeocystis globosa. Virology 341:80-90

Berg GM, Repeta DJ, LaRoche J (2002) Dissolved organic nitrogen hydrolysis rates in axenic cultures of Aureococcus anophagefferens (Pelagophyceae): comparison with heterotrophic bacteria. Appl Environ Microbiol 68:401-404

Bettarel Y, Kan J, Wang K, Williamson KE and 5 others (2005) Isolation and preliminary characterisation of a small nuclear inclusion virus infecting the diatom Chaetoceros cf. gracilis. Aquatic Microb Ecol 40:103-114

Brussaard CPD (2004) Viral control of phytoplankton populations - a review. J Eukaryotic Microbiol 51:125-138

Caron DA, Dennett MR, Moran DM, Schaffner RA, Lonsdale DJ, Gobler CJ, Nuzzi R, McLean TI (2003) Development and application of a monoclonal-antibody technique for counting Aureococcus anophagefferens, an alga causing recurrent brown tides in the Mid-Atlantic United States. Appl Environ Microbiol 69:5492-5502

Cerrato RM, Caron DA, Lonsdale DJ, Rose JM, Schaffner RA (2004) An experimental approach to examine the effect of the hard clam Mercenaria mercenaria on the development of blooms of the brown tide alga Aureococcus anophagefferens. Mar Ecol Prog Ser 281:93-108

Colin SP, Dam HG (2002) Latitudinal differentiation in the effects of the toxic dinoflagellate Alexandrium spp. on the feeding and reproduction of populations of the copepod Acartia hudsonica. Harmful Algae 1:113-125

Cosper EM, Dennison WC, Carpenter EJ, Bricelj VM, Mitchell JG, Kuenstner SH, Colflesh DC, Dewey M (1987) Recurrent and persistent 'brown tide' blooms perturb coastal marine ecosystem. Estuaries 10:284-290

Cosper EM, Dennison WC, Milligan AJ, Carpenter EJ, Lee C, Holzapfel J, Milanese L (1989) An examination of the environmental factors important to initiating and sustaining -brown tide- blooms. In: Cosper EM, Bricelj VM, Carpenter EJ (eds) Novel phytoplankton blooms: causes and impacts of recurrent brown tides and other unusual blooms. Springer, New York, p 317-340

Cosper EM, Garry RT, Milligan AJ, Doall MH (1993) Iron, selenium and citric acid are critical to the growth of the 'brown tide' microalga Aureococcus anophagefferens. In: Toxic phytoplankton blooms in the sea. Proc 5th Int Conf Toxic Marine Phytoplankton. Elsevier, Amsterdam, p 667-673
Cottrell MT, Suttle CA (1991) Wide-spread occurrence and clonal variation in viruses which cause lysis of a cosmopolitan eucaryotic marine phytoplankter, Micromonas pusilla. Mar Ecol Prog Ser 78:1-9

DeYoe HR, Chan AM, Suttle CA (1995) Phylogeny of Aureococcus anophagefferens and a morphologically similar bloom-forming alga from Texas as determined by $18 \mathrm{~S}$ ribosomal RNA sequence analysis. J Phycol 31:413-418

Garry RT, Hearing P, Cosper EM (1998) The characterization of a lytic virus infectious to the brown tide microalga, Aureococcus anophagefferens (Chrysophyceae). J Phycol 34:616-621

Gastrich MD, Anderson OR, Benmayor SS, Cosper EM (1998) Ultrastructural analysis of viral infection in the brown-tide alga, Aureococcus anophagefferens (Pelagophyceae). Phycologia 37:300-306

Gastrich MD, Anderson OR, Cosper EM (2002) Viral-like particles (VLPS) in the alga, Aureococcus anophagefferens (Pelagophyceae), during 1999-2000 brown tide blooms in Little Egg Harbor, New Jersey. Estuaries 25:938-943

Gastrich, MD, Bell JL, Gobler CJ, Anderson OR, Wilhelm SW (2004) Viruses as potential regulators of regional brown tide blooms caused by the alga, Aureococcus anophagefferens: a comparison of bloom years 1999-2000 and 2002. Estuaries 27:112-119

Gobler CJ, Sañudo-Wilhelmy SA (2001) Temporal variability of groundwater seepage and brown tide blooms in a Long Island embayment. Mar Ecol Prog Ser 217:299-309

Gobler CJ, Sañudo-Wilhelmy SA (2003) Cycling of colloidal organic carbon and nitrogen during estuarine plankton blooms. Limnol Oceanogr 48:2314-2320

Gobler CJ, Hutchins DA, Fisher NS, Cosper EM, SañudoWilhelmy SA (1997) Cycling and bioavailability of C, N, P, $\mathrm{Fe}$ and Se released by viral lysis of a marine chrysophyte. Limnol Oceanogr 42:1492-1504

Gobler CJ, Renaghan MJ, Buck NJ (2002) Impacts of nutrients and grazing mortality on the abundance of Aureococcus anophagefferens during a New York brown tide bloom. Limnol Oceanogr 47:129-141

Gobler CJ, Deonarine SN, Leigh-Bell J, Gastrich MD, Anderson OR, Wilhelm SW (2004) Ecology of phytoplankton communities dominated by Aureococcus anophagefferens: The role of viruses, nutrients, and microzooplankton grazing. Harmful Algae 3:471-483

Gobler CJ, Lonsdale DJ, Boyer GL (2005) A synthesis and review of causes and impact of harmful brown tide blooms caused by the alga, Aureococcus anophagefferens. Estuaries 28:726-749

Guillard RRL, Ryther JH (1962) Studies of marine planktonic diatoms. I. Cyclotella nana Hustedt, and Detonula confervacea (Cleve) Gran. Can J Microbiol 8:229-239

Juneau P, Lawrence JE, Suttle CA, Harrison PJ (2003) Effects of viral infection on photosynthetic processes in the bloom-forming alga Heterosigma akashiwo. Aquat Microb Ecol 31: 9-17

Kobler ZS, Zehr J, Falkowski PG (1988) Effects of growth irradiance and nitrogen limitation on photosynthetic energy conversion in photosystem II. Limnol Oceanogr 38: 1646-1665

Lawrence JE, Chan AM, Suttle CA (2001) A novel virus (HaNIV) causes lysis of the toxic bloom-forming alga Heterosigma akashiwo (Raphidophyceae). J Phycol 37 : $216-222$

Lindell D, Jaffe JD, Johnson ZI, Church GM, Chisholm SW (2005) Photosynthesis genes in marine viruses yield proteins during host infection. Nature 438:86-89

Lomas MW, Glibert PM, Berg GM, Burford M (1996) Charac- 
terization of nitrogen uptake by natural populations of Aureococcus anophagefferens (Chrysophyceae) as a function of incubation duration, substrate concentration, light, and temperature. J Phycol 32:907-916

MacKenzie JJ, Haselkorn R (1972) Photosynthesis and the development of blue green algal virus SM-1. Virology 49: 517-521

Milligan AJ, Cosper EM (1997) Growth and photosynthesis of the 'brown tide' microalga Aureococcus anophagefferens in subsaturating constant and fluctuating irradiance. Mar Ecol Prog Ser 153:67-75

Milligan KLD, Cosper EM (1994) Isolation of virus capable of lysing the brown tide microalga, Aureococcus anophagefferens. Science 266:805-807

Mulholland MR, Gobler CJ, Lee C (2002) Peptide hydrolysis, amino acid oxidation and $\mathrm{N}$ uptake in communities seasonally dominated by Aureococcus anophagefferens. Limnol Oceanogr 47:1094-1108

Murray AG, Jackson GA (1992) Viral dynamics - a model of the effects of size, shape, motion, and abundance of single-celled planktonic organisms and other particles. Mar Ecol Prog Ser 89:103-116

Nagasaki K, Yamaguchi M (1997) Isolation of a virus infectious to the harmful bloom causing microalga Heterosigma akashiwo (Raphidophyceae). Aquat Microb Ecol 13: 135-140

Nagasaki K, Yamaguchi M (1998) Intra-species host specificity of $\mathrm{HaV}$ (Heterosigma akashiwo virus) clones. Aquat Microbiol Ecol 14:109-112

Nagasaki K, Ando M, Imai I, Itakura S, Ishida Y (1994) Viruslike particles in Heterosigma akashiwo (Raphidophyceae): a possible red tide disintegration mechanism. Mar Biol 119:307-312

Nagasaki K, Tomaru Y, Tarutani K, Katanozaka N, Yamanaka S, Tanabe H, Yamaguchi M (2003) Growth characteristics and intraspecies host specificity of a large virus infecting the dinoflagellate Heterocapsa circulatisquama. Appl Environ Microbiol 69:2580-2586

Noble RT, Fuhrman JA (1998) Use of SYBR Green I for rapid epifluorescence counts of marine viruses and bacteria. Aquat Microb Ecol 14:113-118

Parkhill JP, Maillet G, Cullen JJ (2001) Fluorescence based maximal quantum yield for photosystem II as a diagnostic of nutrient limitation. J Phycol 37:517-529

Parsons TR, Maita Y, Lalli CM (1984) A manual of chemical and biological methods for seawater analysis. Pergamon Press, Oxford

Pitcher GC, Calder D (2000) Harmful algal blooms of the southern Benguela Current: a review and appraisal of monitoring from 1989 to 1997. S Afr J Mar Sci 22:255-271

Porter KG, Feig YS (1980). The use of DAPI for identifying and counting microflora. Limnol Oceanogr 25: 943-948

Rabinovitch A, Aviram I, Zaritsky A (2003) Bacterial debris an ecological mechanism for coexistence of bacteria and their viruses. J Theor Biol 224: 377-383

Schroeder DC, Oke J, Malin G, Wilson WH (2002) Coccolithovirus (Phycodnaviridae): characterization of a new large dsDNA algal virus that infects Emiliania huxleyi. Arch Virol 147:1685-1698

Editorial responsibility: Gunnar Bratbak, Bergen, Norway
Sengco MR, Anderson DM (2004) Controlling harmful algal blooms through clay flocculation. J Eukaryot Microbiol 51:169-172

Sherman LA (1976) Infection of Synechococcus cedrorum by the cyanophage AS-1M. Virology 71:199-206

Sieburth JMN, Johnson PW, Hargraves PE (1988) Ultrastructure and ecology of Aureococcus anophagefferens gen. et sp. nov. (Chrysophyceae): the dominant picoplankter during a bloom in Narragansett Bay, Rhode Island. Summer 1985. J Phycol 24:416-425

Smayda TJ (1990) Novel and nuisance phytoplankton blooms in the sea: Evidence for a global epidemic. In: Granéli E, Sundstrom B, Edler L, Anderson DM (eds) Toxic marine phytoplankton. Elsevier, New York, p 29-40

Sokal RR, Rohlf FJ (1995) Biometry: the principles and practice of statistics in biological research, 3rd edn. WH Freeman \& Co, New York

Sullivan MB, Waterbury JB, Chisholm SW (2003) Cyanophages infecting the oceanic cyanobacterium Prochlorococcus. Nature 424:1047-1051

Sunda WG, Granéli E, Gobler CJ (2006) Positive feedback and the development and persistence of ecosystem disruptive algal blooms. J Phycol 42:963-974

Suttle CA (2005) Viruses in the sea. Nature 437:356-361

Suttle CA, Chan AM (1993) Marine cyanophages infecting oceanic and coastal strains of Synechococcus-abundance, morphology, cross- infectivity and growth characteristics. Mar Ecol Prog Ser 92: 99-109

Suttle CA, Chan AM (1995) Viruses infecting the marine prymnesiophyte Chrysochromulina spp.: isolation, preliminary characterization and natural abundance. Mar Ecol Prog Ser 118:275-282

Tarutani K, Nagasaki K, Yamaguchi M (2000) Viral impacts on total abundance and clonal composition of harmful bloom-forming phytoplankton Heterosigma akashiwo. Appl Environ Microbiol 66:4916-4920

Tarutani K, Nagasaki K, Itakura S, Yamaguchi M (2001) Isolation of a virus infecting the novel shellfish-killing dinoflagellate Heterocapsa circularisquama. Aquat Microb Ecol 23:101-111

Thingstad TF, Lignell R (1997) Theoretical models for the control of bacterial growth rate, abundance, diversity and carbon demand. Aquat Microb Ecol 13:19-27

Thyrhaug R, Larsen A, Thingstad TF, Bratbak G (2003) Stable coexistence in marine algal host-virus systems. Mar Ecol Prog Ser 254:27-35

Wilhelm SW, Poorvin L (2001) Quantification of algal viruses in marine samples. In: Paul JH (ed) Methods in microbiology, Vol 30. Marine microbiology. Academic Press, New York, p 53-66

Wilhelm SW, Suttle CA (1999) Viruses and nutrient cycles in the sea. BioScience 49:781-788

Wommack KE, Colwell RR (2000) Virioplankton: viruses in aquatic ecosystems. Microbiol Molecular Biol Rev 64: 69-114

Zingone A, Natale F, Biffali E, Borra M, Forlani G, Sarno D (2006) Diversity in morphology, infectivity, molecular characteristics and induced host resistance between two viruses infecting Micromonas pusilla. Aquat Microb Ecol 45:1-14

Submitted: September 15, 2006; Accepted: January 12, 2007 Proofs received from author(s): March 15, 2007 